\title{
REVIEW
}

\section{Charles R. Gallagher, S.J. Vatican Secret Diplomacy: Joseph P. Hurley and Pope Pius XII}

New Haven and London: Yale University Press, 2008. Hardcover, xi +283 pp. Reviewed by Raymond Cohen, Corcoran Chair, Center for Christian-Jewish Learning, Boston College

Charles Gallagher has enterprisingly made use for the first time of the archive of Archbishop Joseph P. Hurley, Bishop of the diocese of St. Augustine, Florida, to write the revealing biography of a Vatican diplomat who was a severe in-house critic of Pius XII's policy of appeasement and reticence on the extermination of the Jews.

Joseph Hurley (1894-1967) was the son of poor Irish immigrant parents who grew up in Cleveland, Ohio in a dingy home near the railroad tracks. An altar boy in church, he was a bright student and a good sportsman. His favorite sport was boxing and throughout his life he never shirked a scrap. He was imbued with two passions, love of Church and love of country. He did not like Jews. After his plans to attend, first West Point Military Academy, then Harvard Law School, fell through, he chose the priesthood and was ordained in 1919.

At St. Mary's Seminary Hurley was befriended by Edward Mooney, the future cardinalarchbishop of Detroit. In 1928 he was invited by Mooney, by then apostolic delegate to India, to be his secretary. Observing Mooney's tough tactics negotiating the Mylapore Agreement, which ended the system of local Portuguese patronage in Church appointments, Hurley drew the conclusion that a "diplomacy of inflexibility" paid off. In 1930 Mooney was appointed apostolic delegate to Japan. When he fell out with the bellicose Japanese authorities in 1933 Hurley, who had no formal diplomatic or legal training - but had served an apprenticeship under Mooneybecame chargé of mission.

It was in this post that Hurley first made his mark. Instructed to "hold on" until the arrival of a new apostolic delegate, the feisty American determinedly faced down a threat to religious freedom. Catholic children in Nagasaki were barred from going to chapel by the Japanese government. Hurley refused to buckle under pressure and authorized the students to attend church, rightly judging that the authorities would back down.

This was Hurley's first, but not his last encounter with totalitarianism. Confronting dictatorships and standing up for Catholics' rights in the face of persecution were to be constant themes of his subsequent career. In 1934 Hurley officially entered the Vatican Secretariat of State and during the Nazi period was the only American in the Church's foreign service, serving as Rome liaison for the apostolic delegation in Washington and resident expert on U.S.-Vatican relations.

In this capacity he played a key, hitherto unrevealed part in the affair of Fr. Charles E. Coughlin, the rabble-rousing "radio priest", whose strident opposition to the New Deal was an embarrassment to the Roosevelt administration and whose Jew-baiting was a gift to Nazi propaganda. Hurley's assigned task, which he failed in, was to moderate the unruly priest. In November 1938 following the Kristallnacht pogrom-the beginning of the end of German Jewry-Fr. Coughlin made a virulently anti-Semitic broadcast blaming the Jews for their own fate. What was to be done? The Church kept silent. Hurley wrote from Rome that "nobody seems bothered about it here" and criticized Jewish organizations for making "too much of an 
outcry about the speech" (p. 61). The Vatican feared that public denunciation of Coughlin would spawn a Catholic backlash in the United States and be exploited by the Nazis and Fascists against Church interests in Europe. To avoid this Monsignor Domenico Tardini, a senior Vatican official, actually proposed backing Fr. Coughlin.

Following a visit by British Prime Minister Neville Chamberlain to the Vatican in January 1939 at which Hurley acted as interpreter for Pius XI, the pope was reinforced in his view that Hitler posed a greater-and certainly more immediate-threat to the Catholic Church than Stalin. Hurley was in full agreement. But within weeks Pius XI was dead. His successor, Pius XII, reversed Vatican policy, assigning the Communist threat greater priority and opting to appease Hitler. Fr. Gallagher argues that Pius XII's long-time dread of Communism spilled over into a conviction that even the United States was ripe for a Communist takeover. "The great danger in America is that it will go communist," the then Cardinal Pacelli reportedly told President Roosevelt in 1936 (pp. 87-88).

Behind the scenes Hurley determined, as an American patriot, to do all he could to assist President Roosevelt's growing opposition to Nazism and Fascism. In October 1939 he was thanked by the president for having presidential statements published in the Vatican's Osservatore Romano, the only independent news outlet in Italy at that time. At first Hurley hoped to harmonize his two loyalties, to pope and president. But he soon became disenchanted with Pius XII's impartiality in the midst of "a war for Christian Civilization" (pp. 89-90) and his reluctance to condemn Germany for the invasion of Poland. "Any man who is not moved by a profound moral indignation is thereby disqualified as a moral force," he wrote in his notes (pp. 97-98).

In his first encyclical of October 20,1939, Summi Pontificatus, Pius XII defined the duties of Catholics in wartime: prayer, mortification, and penance. Hurley, who translated the document into English, implicitly challenged it in an extraordinary broadcast over Vatican Radio on July 1, 1940, following the fall of France. Pacifists were wrong, he opined. The Allies were "defending justice." Evoking the Gospels he argued that Christ himself would have admitted "that two nations could be at war and one of them be in the right" (p. 99).

Hurley's position had now become untenable. In his notes he lamented Pius XII's weakness, which had "come to light with the first appearance of danger." He wondered "Why are the good so often weak, or dumb, or wrong minded?" (p. 104). On August 13, 1940 the bishop of the diocese of St. Augustine, Florida died. With unprecedented haste Hurley was appointed to the post. It was an example of the Vatican tradition of promoveatur ut removeatur-let him be promoted in order to be removed. Pius XII was absent from his critic's Vatican consecration.

For the duration of the war Hurley, in collaboration with the U.S. State Department, threw himself into public diplomacy, speaking, broadcasting, and writing. He did not conceal his disapproval of Pius XII's shrouded pronouncements. In a broadcast on CBS on July 6, 1941 he explicitly denounced "the murderous hosts of Nazi Germany." "We will call things by their real names," he told his audience, hinting at a 1937 address by Pius XI condemning Nazi atrocities (p. 122). Archbishop Cicognani, the apostolic delegate in Washington, carpeted the outspoken bishop. It was "inopportune," he told Hurley, for religious leaders to make moral judgments upon political topics. "Don't say any more" (p. 126).

Hurley also underwent a change of heart on the Jews at this time, speaking out against Catholic anti-Semitism and condemning in general terms the German concentration camps in Poland. This was a full year and a half before Pius XII's 1942 Christmas Message obliquely referred to 
those who "sometimes only because of their nationality and race, have been consigned to death or to a slow decline" (p. 147).

Hurley's finest hour came with an editorial published in the Florida Catholic on April 9, 1943 explicitly denouncing the extermination of the Jewish people. Not mincing his words he declared that the death camps were "a criminal effort to eradicate the Jews." All Christians must condemn the "orgies of extermination" sweeping Nazi-occupied Europe. Hinting at his disappointment with the pope's abdication of leadership he called on Christians to "take the lead in opposing in every way possible the barbarism that rages unchecked" under the swastika flag (p. 149).

At the end of the war Hurley was unexpectedly given a new diplomatic posting. With Germany defeated and Yugoslavia under Communist rule, the Vatican now needed an envoy in Belgrade who could work closely with the American embassy. Initially the arrangement worked well: Hurley supplied his old State Department friends with intelligence, they interceded on behalf of Catholics in jeopardy. But soon his position unraveled. His fervent support of Croat Archbishop Stepinac, on trial for collaboration with the pro-Nazi Ustasha, cast doubt on his good judgment. Then, as the split between Tito and Stalin widened, Hurley's penchant for a "diplomacy of inflexibility" fell out of favor. By late 1949 he was complaining about the Vatican's "hand-wringing passivity" and the pope's lack of leadership (p. 191). Within a year he was sent home for good.

In his later years Hurley became increasingly reactionary. He persisted with his anti-Tito crusade, was deeply suspicious of the State Department, and identified with Senator Joseph McCarthy. Later he opposed détente, fobbed off the Reverend Martin Luther King's personal request to help in the fight for desegregation, and objected that the attention paid by the Second Vatican Council to anti-Semitism was excessive. He continued to mull over his differences with Pius XII, who had twice curtailed his diplomatic career and relegated him to a diocesan backwater.

The disagreement between the two men must give us pause. Clearly the responsibility of a pope is of a very different order from that of a middle-level official. The arguments used in Vatican circles to justify Pius XII's aloof policy towards the extermination of the Jews were summarized by the United States' resident envoy to the Vatican, Harold Tittmann. They included a lack of uncontestable proof, the impracticality of verifying all the various alleged humanitarian violations in wartime, the danger of irreparable errors of judgment, the assertion that the pope had spoken in general but unmistakable terms, common knowledge that the views of local bishops reflected the position of the pope, the belief that open condemnation would do more harm than good, the need to be even-handed between Nazis and Bolsheviks, and the fear of alienating the German faithful should Germany lose the war. ${ }^{1}$ Reticence, in short, was presented as both inescapable and prudent given the logic of the situation. Hurley's contemporary critique gravely undermines this case because it is that of an insider motivated by deep concern for the Church who was privy to the facts available to the pope at the time.

Hurley's view was that a pope faced by clear and present evil had to provide unambiguous moral guidance to those who looked to him for leadership. He had to decide on the facts without evasion and condemn that evil in the most explicit language. Confronted by mass murder on an unprecedented scale the natural human reaction is one of disbelief and denial. Only when a pontiff-the supreme moral authority on earth-spoke out in the plainest terms could lesser folk grasp the realities of the situation and do their moral duty as Christians. Of course, the righteous

\footnotetext{
${ }^{1}$ See Harold Tittmann, Inside the Vatican of Pius XII: The Memoir of an American Diplomat during World War II (New York: Doubleday, 2004) pp. 119-20, 124-25.
} 
few needed no instruction. But without clear leadership at the top how could local bishops and their flocks be expected to stand up and be counted? With the same facts at his disposal as his masters, Hurley grasped the dimensions of the tragedy and the need for moral leadership where they did not. He saw through the specious argument to even-handedness and the fallacy that to speak out as the Nazi machinery of extermination worked at full capacity could somehow make the situation worse. Above all this very political diplomat understood that the pope must provide a fearless moral lead; if not him, then who?

We should be grateful to Charles Gallagher for a meticulous piece of original research. He adds significantly to our knowledge of Vatican thinking during the Holocaust. He also provides us with a fresh perspective from which to appraise the quality of moral guidance provided by Pius XII during the greatest challenge ever faced by a spiritual leader. In the final analysis Gallagher's account challenges the special pleading used both then and now. 